\title{
WATERLOGGING TOLERANCE OF SOYBEAN
}

\author{
R. Ara ${ }^{1}$, M. A. Mannan ${ }^{1 *}$, Q. A. Khaliq ${ }^{1}$ and M. M. Uddin Miah ${ }^{2}$ \\ ${ }^{1}$ Department of Agronomy, Bangabandhu Sheikh Mujibur Rahman Agricultural University, Gazipur-1706, \\ Bangladesh \\ ${ }^{2}$ Department of Agroforestry and Environmental, Bangabandhu Sheikh Mujibur Rahman Agricultural University, \\ Gazipur-1706, Bangladesh \\ *Corresponding author: mannanbsmrau@yahoo.com
}

Key words: soybean, water logging tolerance, dry matter accumulation and yield.

Soybean (Glycine max L.) is one of the most important oil crops and rich in protein which have various uses for human food. Water logging induced several physiological disturbances in growth, dry matter, photosynthesis and pod formation that resulted in lower yield (Solaiman et al., 2007; Pociecha et al., 2008; Celik and Turhan, 2011; Hasanuzzaman et al. 2016). Waterlogging reduced seed yield primarily by reducing the number of pods per plant and pod setting (Ahmad et al., 2003; Ahmed et al., 2002). Linkemer et al. (1998) identified some vegetative stages sensitive to waterlogging as well as some reproductive stages. Soybean germplasms display a spectrum of waterlogging tolerance capability. The degree of flooding tolerance of soybean germplasms varies with the developmental stages. The present study was, therefore undertaken to evaluate the effect of excess water on dry matter accumulation and yield of soybean.

A field experiment was carried out at the Agronomy field, Bangabandhu Sheikh Mujibur Rahman Agricultural University, Salna, Gazipur during December, 2013 to April 2014. The treatments were four soybean genotypes viz. i) AGS 313 ii) G 00351 iii) BD Soybean 4 (Bangladesh Soybean 4) iv) G 00197 and three waterlogging i) Control (no waterlogging) ii) waterlogging at R1 (Blooming) stage iii) waterlogging at R4 (full pod) stages for one week. These four genotypes were screened out from 50 soybean genotypes at early stage waterlogging on the basis of relative shoot dry matter accumulation. The experiment was laid out in split- plot design with three replications where waterlogging treatments were assigned in main plot and four soybean genotypes to sub-plots. Waterlogging plot area was surrounded by polythene anchored into the ground and extending $30 \mathrm{~cm}$ above the ground to hold water. Seed of each soybean genotypes was sown in December 2013 maintaining 30 $\mathrm{cm}$ line to line and $5 \mathrm{~cm}$ plant to plant distance. After sowing of seeds, light irrigation was given to ensure uniform germination of seeds. Control plots were irrigated at 30 and 50 DAS (days after sowing) all over the growing period. Waterlogging treated plots were irrigated at Blooming and Full pod stages. Water level of the each flooding treatments was maintained at 2.5 to $5.0 \mathrm{~cm}$ above ground every alternate day during the 7-day period. The plots were kept weed free. The experimental area was fertilized with 50,160,110,100, $8 \mathrm{~kg} \mathrm{ha}^{-1}$ Urea, TSP, MoP, Gypsum and Boron, respectively. The entire amount of TSP, MoP, Gypsum, Boron and half of urea were applied as basal dose. Rest urea was applied before flowering. Necessary plant protection measures were taken to maintain optimum growth of the plants. At maturity five plants were randomly selected and plants were segmented into leaf, stem and roots and oven dried for 72 hours at $70^{\circ} \mathrm{C}$. The observations on t dry matter per plant (including root), and yield attributes were recorded. Seed yield was adjusted to $12 \%$ moisture content. The data recorded on different parameters were statistically analyzed and the differences between the treatments means were compared by LSD test (Gomez and Gomez, 1984). 
106

ARA et al.

Shoot dry weight of all soybean genotypes were significantly affected by waterlogging (Fig. 1). Reduction was higher when plant was subjected to waterlogging at R4 stage than R1 stage. The highest relative shoot dry matter $(69.35 \%)$ was accumulated by genotype AGS 313 , while G00351 and BD soybean-4 produced only 66.97 and $65.29 \%$, respectively and the lowest (54.21\%) in genotype G00197 (54.21\%) at R4 stage of flooding. A similar trend in shoot growth was found when flooding treatment was imposed at R1 stage. The reduction in shoot dry matter is probably due to reduction in shoot length and branching. Tolerant genotypes with vigorous shoot and root growth were better able to tolerate transient waterlogging (Hartley et al., 1993).

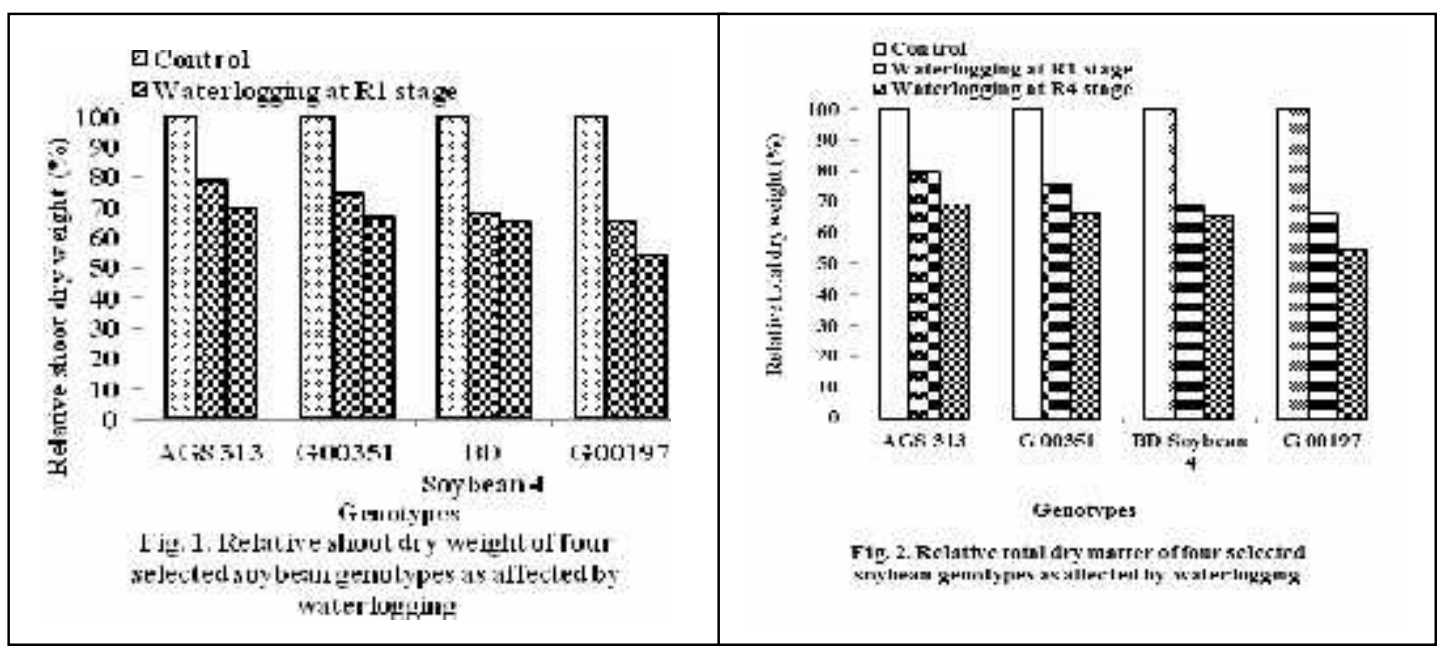

Reduction in total dry matter (DM) production and the variation in DM production among genotypes due to waterlogging are in Fig. 2. Both R1 and R4 stages of waterlogging affected significantly the total dry matter production in all the soybean genotypes. Total dry matter reduction due to waterlogging was lower at $\mathrm{R} 4$ stage than that at $\mathrm{R} 1$ stage. Waterlogging induced differences in total dry matter production among the genotypes were caused by the differences in the reduction of root, leaf and stem dry matter than control. The minimum reduction in total dry matter was noticed in genotype AGS $313(31.05 \%)$, whereas the maximum (45.43\%) in G00197 (Fig. 2). The dry matter reduction in G00351 and BD soybean 4 were $(34 \%)$ and $(35 \%)$, respectively. The total dry matter in genotype AGS 313 was less affected even at R1 stage waterlogging, which could be attributed to more efficient production of leaf, stem, and root dry matter. Waterlogging generally reduced the growth of plant components resulting in low total dry weight (TDW). Tolerant genotypes had more dry matter because they were lesser affected by waterlogging. The tolerant genotypes maintained greater root, shoot and leaf dry matter under waterlogging than the sensitive cultivars.

Waterlogging reduced significantly number of pods per plant compared to that in control in all the four soybean genotypes. The reduction was smaller at R1 stage waterlogging compared to that at R4 stage. In control treatment, Bangladesh soybean 4 produced the highest number of pods per plant (85.86) while waterlogging treatment was imposed at R1 and at R4 stage was 66 and 53, respectively (Table 1). The highest relative pods number per plant produced by genotype AGS 313 which was $90.86 \%$ at R1 stage and $84.78 \%$ at R4 stage of waterlogging. The highest relative pods per plant in genotype AGS 313 might have attributed to a lower reduction in shoot dry matter as well as total dry matter. Waterlogging 
Waterlogging Tolerance of Soybean

also reduced the average number of seeds per pod significantly in all the soybean genotypes studied (Table 1). The number of seeds per pod was affected a little by R1 stage flooding in all the genotypes. Under R4 stage flooding, the highest relative seeds number per pod was produced by the genotype AGS 313 (72.04\%), followed by G 00351 (66.47\%), BD soybean $4(64.82 \%)$ and the lowest by G 00197 (59.25\%). The highest seeds number per pod in genotype AGS 313 was probably due to the lowest reduction in pollen fertility due to waterlogging as reported by Omae et al. (2005). Waterlogging induced reduction in seeds per pod was higher at later stage waterlogging as reported by Umaharan et al. (1997) and Zhou and Lin (1995).

Seed weight decreased significantly at R1 stage flooding, which further decreased at R4 stage (Table 2). At R1 stage flooding, 100-seed weight ranged from 7.91 to $17.93 \mathrm{~g}$, whereas at R4 stage waterlogging from $5.81 \mathrm{~g}$ to $17.89 \mathrm{~g}$. Relative grain weight was the highest in AGS $313(87.06 \%)$, followed by G $00351(82.25 \%)$ and BD soybean $4(72.10 \%)$, and lowest in $\mathrm{G} 00197(71.55 \%)$ at R4 stage waterlogging. A remarkable reduction in the size of seeds was observed at R4 stage water logging in all the genotypes.

Table 1. Number of pods plant ${ }^{-1}$ and number of seeds $\operatorname{pod}^{-1}$ of four selected soybean genotypes as affected by waterlogging

\begin{tabular}{|c|c|c|c|c|c|c|}
\hline \multirow[t]{2}{*}{ Genotypes } & \multicolumn{3}{|c|}{ Number of pods plant ${ }^{-1}$} & \multicolumn{3}{|c|}{ Number of seeds pod ${ }^{-1}$} \\
\hline & Control & $\begin{array}{l}\text { Flooding at } \\
\text { R1 stage }\end{array}$ & $\begin{array}{l}\text { Flooding at } \\
\text { R4 stage }\end{array}$ & Control & $\begin{array}{l}\text { Flooding at } \\
\text { R1 stage }\end{array}$ & $\begin{array}{l}\text { Flooding at } \\
\text { R4 stage }\end{array}$ \\
\hline AGS 313 & 28.46 & $\begin{array}{c}25.86 \\
(90.86)\end{array}$ & $\begin{array}{c}24.13 \\
(84.78)\end{array}$ & 1.86 & $\begin{array}{c}1.52 \\
(81.72)\end{array}$ & $\begin{array}{c}1.34 \\
(72.04)\end{array}$ \\
\hline G 00351 & 20.53 & $\begin{array}{c}17.06 \\
(83.09)\end{array}$ & $\begin{array}{c}12.93 \\
(62.98)\end{array}$ & 1.73 & $\begin{array}{c}1.32 \\
(76.30)\end{array}$ & $\begin{array}{c}1.15 \\
(66.47)\end{array}$ \\
\hline BD Soybean 4 & 85.86 & $\begin{array}{l}65.66 \\
(76.47)\end{array}$ & $\begin{array}{c}53.35 \\
(62.21)\end{array}$ & 1.99 & $\begin{array}{c}1.46 \\
(73.33)\end{array}$ & $\begin{array}{c}1.29 \\
(64.82)\end{array}$ \\
\hline G 00197 & 53.26 & $\begin{array}{c}34.86 \\
(65.45)\end{array}$ & $\begin{array}{c}25.25 \\
(47.40) \\
\end{array}$ & 1.89 & $\begin{array}{c}1.22 \\
(64.45) \\
\end{array}$ & $\begin{array}{c}1.12 \\
(59.25) \\
\end{array}$ \\
\hline $\operatorname{LSD}_{(0.05)}$ & & 8.55 & & & 0.32 & \\
\hline CV (\%) & & 13.20 & & & 11.42 & \\
\hline
\end{tabular}

Values in parenthesis indicates per cent of control

Seed yield was reduced by waterlogging in all the soybean genotypes studied and the decreasing rate was higher in R4 stage than R1 stage. Seed yield of different genotypes ranged from 1.69 to $2.70 \mathrm{t} \mathrm{ha}^{-1}$ under normal conditions and that from 1.10 to 2.09 and 0.80 to $2.84 \mathrm{t} \mathrm{ha}^{-1}$ respectively under $\mathrm{R} 1$ and $\mathrm{R} 4$ stage flooding conditions. (Table 2 ). The highest relative seed yield was found in genotype AGS 313 at both the waterlogging stages and the lowest was genotype G 00197. The highest relative pod number per plant and individual seed weight in genotype AGS 313 mostly contributed to the highest relative seed yield of this genotype.

Waterlogging reduced seed yield primarily by reducing the number of pod per plant and pod setting. The yield of soybean subjected to wet conditions at the vegetative growth stage may be reduced by 17-43\% (Oosterhuis et al., 1990; Scott et al., 1990). Genotypic sensitivity to waterlogging could be related to the level of endogenous plant hormones, which increase dropping of flowers and/or the loss of pod setting, as also observed in other crops (Lakitan et al., 1992; Umaharan et al., 1997) 
ARA et al.

Table 2. 100-seed weight and grain yield $\left(\mathrm{t} \mathrm{ha}^{-1}\right)$ of four selected soybean genotypes as affected by waterlogging

\begin{tabular}{|c|c|c|c|c|c|c|}
\hline \multirow[t]{2}{*}{ Genotypes } & \multicolumn{3}{|c|}{100 -seed weight $(\mathrm{g})$} & \multicolumn{3}{|c|}{ Seed yield $\left(\mathrm{t} \mathrm{ha}{ }^{-1}\right)$} \\
\hline & Control & $\begin{array}{l}\text { Flooding at } \\
\text { R1 stage }\end{array}$ & $\begin{array}{l}\text { Flooding at } \\
\text { R4 stage }\end{array}$ & Control & $\begin{array}{c}\text { Flooding at } \\
\text { R1 stage }\end{array}$ & $\begin{array}{c}\text { Flooding at } \\
\text { R4 stage }\end{array}$ \\
\hline AGS 313 & 18.25 & $\begin{array}{c}17.93 \\
(98.24)\end{array}$ & $\begin{array}{c}15.89 \\
(87.06)\end{array}$ & 2.70 & $\begin{array}{c}2.09 \\
(77.40)\end{array}$ & $\begin{array}{c}1.84 \\
(68.14)\end{array}$ \\
\hline G 00351 & 12.35 & $\begin{array}{c}12.08 \\
(97.81)\end{array}$ & $\begin{array}{c}10.19 \\
(82.25)\end{array}$ & 2.54 & $\begin{array}{c}1.73 \\
(68.11)\end{array}$ & $\begin{array}{c}1.50 \\
(59.05)\end{array}$ \\
\hline BD Soybean 4 & 7.60 & $\begin{array}{c}7.30 \\
(96.05)\end{array}$ & $\begin{array}{c}5.48 \\
(72.10)\end{array}$ & 2.28 & $\begin{array}{c}1.50 \\
(65.78)\end{array}$ & $\begin{array}{c}1.12 \\
(49.12)\end{array}$ \\
\hline G 00197 & 8.12 & $\begin{array}{c}7.91 \\
(97.41)\end{array}$ & $\begin{array}{c}5.81 \\
(71.55)\end{array}$ & 1.69 & $\begin{array}{c}1.10 \\
(65.08)\end{array}$ & $\begin{array}{c}0.80 \\
(47.33)\end{array}$ \\
\hline $\begin{array}{l}\operatorname{LSD}_{(0.05)} \\
\operatorname{CV}(\%)\end{array}$ & & $\begin{array}{c}0.92 \\
14.77\end{array}$ & & & $\begin{array}{c}0.36 \\
12.17\end{array}$ & \\
\hline
\end{tabular}

Values in parenthesis indicates per cent of control

Based on the study it may be concluded that waterlogged affects adversely the dry matter accumulation and yield of soybean plants and the reduction was higher at Full pod stage flooding than in Blooming stage flooding. The genotype AGS 313 showed higher waterlogging tolerance while genotype G00197 was susceptible in terms of dry matter accumulation and yield performance.

\section{Acknowledgement}

We are grateful to Research Management Committee (RMC), Bangabandhu Sheikh Mujibur Rahman Agricultural University for funding the research work.

\section{References}

Ahmad, R., M. Ikraam, E. Ullah and A. Mahmood. 2003. Influence of different fertilizer levels on the growth and productivity of three mungbean cultivars. Int. J. Agric. Biol. 5:335-338.

Ahmed, S., H. Higuchi, E. Nawata and T. Sakuratani. 2002. Effects on exogenous ABA and ethylene application and waterlogging on photosynthesis in mungbean (Vigna radiata L.cv. Wilczak). J. Trop. Agric. 46:166-174.

Celik, G. and E. Turhan. 2011. Genotypic variation in growth and physiological responses of common bean (Phaseolus vulgaris L.) seedlings to flooding. Afr. J. Biotechnol. 10:73727380.

Gomez, A. A. and A. A. Gomez. 1984. Statistical procedure of agricultural Research. John Wiley and Sons. New york. Pp.20-2015

Hartley, R., R. Lawn and D. Byth. 1993. Genotypic variation in growth and seed yield of soybean (Glycine max L. Merr.) in saturated soil culture. Aust. J. Agric. Res. 44:689-702.

Hasanuzzaman, M., K. Nahar, A, Rahman, J.A. Mahmud, M.S. Hossain and M. Fujita (2016) Soybean production and environmental stresses. In: Miransari M. (ed) Environmental Stresses in Soybean Production: Soybean Production, Volume 2. Academic Press/Elsevier Inc., New York. USA. ISBN: 978-0-12-801535-3 
Waterlogging Tolerance of Soybean

Lakitan, B., D. B. Wolfe and R. W. Zobel. 1992. Flooding affects snap bean yield and genotypic variation in leaf gas exchange and root growth response. J. Amer. Soc. Hort. Sci. 117:711-716.

Linkemer, G., J. E. Board and M. E. Musgrave. 1998. Waterlogging effects on growth and yield components in late-planted soybean. Crop Sci. 38:1576-1584.

Omae, H. A., Y. Kumar, K. Egawa, Kshiwaba and M. Shono. 2005. Genotypic differences in plant water status and relationship with reproductive responses in Snapbean (Phaseolus vulgaris L.) during water stress. Jpn. J. Trop. Agric. 49: 1-7.

Oosterhuis, D. M., H. D. Scott, R. E. Hampton and S. D. Wullschleger. 1990. Physiological response of two soybean (Glycine max L. Merr.) cultivars to short-term flooding. Environ. Exp. Bot. 30:85-92.

Pociecha, E., J. Koscielniak and W.Filek. 2008. Effect of root flooding and stage of development on the growth and photosynthesis of field bean (Vicia faba L. minor) Acta Physiol Plant. 30:529-535.

Scott, H. D., J. De Angulo, L. S. Wood and D. J. Pitts. 1990. Influence of temporary flooding at three growth stages on soybean growth on a clayey soil. J. Plant Nutr. 13:1045-1071.

Solaiman, Z., T. D. Colmer, S. P. Loss, B. D. Thomson, and K. H. M. Siddique. 2007. Growth responses of cool-season grain legumes to transient water logging. Aust $\mathrm{J}$ Agric Res. 58:406-412.

Zhou, W. and X. Lin. 1995. Effects of waterlogging at different growth stages on physiological characteristics and seed yield of winter rape (Brassica napus L.) Field Crops Res. 44:103-110. 